DOI : https://doi.org/10.47828/iianaasian.v9i1.57

\title{
Analisis Kebijakan Pemerintah Daerah Kota Cilegon Dalam Penetapan Desa Wisata Watu Lawang
}

\author{
Fuqoha' \\ ${ }^{1}$ Fakultas Ilmu Sosial, Ilmu Politik dan Ilmu Hukum, Universitas Serang Raya. \\ Jl. Raya Serang Cilegon, KM. 5, Taktakan, Kota Serang
}

\section{ARTICLEINFO}

Article history :

Received 13/03/2021

Received in revised form $20 / 03 / 2021$

Accepted 24/02/2021

\begin{abstract}
Agro-tourism is one of the tourist attractions for regional and national tourists. Watu Lawang has potential tourism object to become an agro-tourism that has been determined by the Local Tourism and Culture Department of Cilegon City has not been implemented optimally. The tourism sector, which is designated as the leading sector in increasing the country's economic growth, is a challenge for local governments in optimizing tourism potential. The purpose of developing tourism and regional culture as a tourism destination is a form of increasing foreign exchange for the region in particular and the economy of the local community or region in general. The purpose of this study was to analyze policies, strategies and constraints in the development and development of tourism objects in Watu Lawang agro-tourism in the city of Cilegon. The research method used is descriptive qualitative research and normative juridical approach, data and document collection is done through interviews and observations. The results showed that the tourism policies have been formed from national policies to regional policies. Various strategies have been formulated by the ministry of tourism and the tourism office in the regions in order to develop the potential for tourism objects. The potential of the Watu Lawang agro-tourism object is not optimal due to several factors, including accessibility, facilities, human resources, geographic and sociological location.
\end{abstract}

Keywords: Policy Analysis; Tourism; Agro-Tourism

\begin{abstract}
Abstrak
Wisata Agro menjadi salah satu daya tarik wisata bagi wisatawan daerah maupun nasional. Potensi obyek wisata Watu Lawang sebagai salah satu obyek wisata agro yang ditetapkan Dinas Pariwisata dan Kebudayaan Kota Cilegon belum diselenggarakan secara optimal. Sektor kepariwisataan yang ditetapkan sebagai leading sector dalam peningkatan pertumbuhan perekonomian negara menjadi tantangan bagi pemerintah daerah dalam mengoptimalisasi potensi wisata. Tujuan pengembangan pariwisata dan budaya daerah sebagai destinasi pariwisata adalah bentuk peningkatan devisa bagi daerah secara khusus dan perekonomian masyarakat lokal atau daerah pada umumnya. Tujuan penelitian ini untuk menganalisis kebijakan, strategi dan kendala dalam pembangunan dan pengembangan obyek wisata pada wisata agro Watu Lawang di kota Cilegon. Metode penelitian yang digunakan menggunakan penelitian deskriptif kualitatif dan pendekatan yuridis normatif,
\end{abstract}


pengumpulan data dan dokumen dilakukan dengan melalui wawancara dan observasi. Hasil penelitian menunjukkan bahwa kebijakan kepariwisataan telah terbentuk dari kebijakan nasional hingga kebijakan daerah. Telah tersusun berbagai strategi yang ditetapkan oleh kementerian kepariwisataan maupun dinas pariwisata di daerah dalam upaya pembangunan dan pengembangan potensi obyek wisata. Potensi obyek wisata agro watu lawang yang tidak optimal disebabkan beberapa faktor antara lain aksesibilitas, fasilitas, sumber daya manusia, letak geografis dan sosiologis.

Kata kunci: Analisis Kebijakan; Kepariwisataan; Wisata Agro.

${ }^{*}$ Fuqoha

E-mail : fuqoha23@gmail.com

\section{PENDAHULUAN}

Sistem ketatanegaraan Indonesia sebagaimana dituangkan dalam konstitusi negara Republik Indonesia menetapkan prinsip otonomi daerah, dengan konsepsi bahwa negara Indonesia dibagi atas daerah-daerah berupa daerah provinsi dan daerah kabupaten/kota. Dengan adanya ketentuan tersebut, maka pemerintah daerah memiliki kewenangan untuk mengurusi urusan dan kepentingan daerah sesuai kewenangan yang diatur dan dituangkan dalam perundangundangan. Prinsip otonomi daerah memberikan kewenangan untuk mengatur dan mengurus pemerintahan seluas-luasnya kecuali yang diatur lain dalam undangundang. Konsepsi otonomi daerah merumuskan suatu penyelenggaraan negara yang sinergitas antara pemerintah pusat dan pemerintah daerah dalam rangka mewujudkan tujuan negara.

Konsepsi otonomi daerah memberikan hak, wewenang dan kewajiban bagi daerah untuk mengurus dan mengatur rumah tangganya sendiri sesuai dengan peraturan perundang-undangan. Diantara tujuan prinsip otonomi daerah adalah meningkatkan kesejahteraan masyarakat, pelayanan umum dan daya saing daerah. Kesejahteraan masyarakat meliputi berbagai macam dimensi seperti politik, ekonomi, sosial, budaya, pertahanan dan keamanan (POLEKSOSBUDHANKAM). Daerah berdaya saing merupakan salah satu instrumen penyelenggaraan otonomi daerah yang hakikatnya untuk meningkatkan kemampuan ekonomi lokal berdaya saing. (Sunarno, 2012:10)

\section{Pemerintah}

Republik Indonesia melalui Presiden Joko Widodo menyampaikan dan menetapkan bahwa pariwisata menjadi leading sector yang berarti bahwa pariwisata memiliki potensi peningkatan perekonomian nasional. Dalam sosialisasi yang dikemukakan oleh Kementerian Pariwisata bahwa pariwisata merupakan salah satu sektor unggulan dalam pembangunan Indonesia. (Thaib dalam djppr.kemenkeu.go.id diunduh 26/02/2021) Pembangunan dan pengembangan pariwisata di daerah merupakan tanggungjawab dan kewenangan pemerintah daerah yang bersinergi dengan kebijakan dan strategi nasional dalam bidang kepariwisataan. Oleh karena itu, salah satu instrumen yang dapat dikembangkan sebagai destinasi pariwisata adalah kebudayaan. Siswanto Sunarno menjelaskan peran penting pemerintah daerah dalam pengelolaan kebudayaan agar mengarah pada peningkatan kualitas 
budaya tanpa menghilangkan nilai budaya luhur. (Sunarno, 2012:10) Dalam tatanan implementasi budaya sebagai destinasi pariwisata perlu disesuaikan terhadap tantangan globalisasi yang tidak dapat dihindari. Dengan demikian upaya nasionalisasi dan internasionalisasi budaya daerah sebagai destinasi pariwisata merupakan tantangan pemerintah daerah dalam peningkatan dan pengembangan sektor pariwisata.

Pembangunan dan pengembangan sektor pariwisata dapat dipengaruhi oleh ptensi dan daya tarik wisata. Daya tarik wisata dalam Peraturan Daerah Provinsi Banten Nomor 6 Tahun 2019 Tentang Rencana Induk Pengembangan Kepariwisataan Provinsi Banten 2018-2025 merupakan segala sesuatu yang memiliki keunikan, keindahan, dan nilai yang berupa keanekaragaman kekayaan alam, budaya, dan hasil buatan manusia yang menjadi sasaran atau tujuan kunjungan wisata. Kebijakan yang dikeluarkan pemerintah daerah provinsi banten dalam bentuk Rencana Induk Pengembangan Kepariwisataan Provinsi (RIPPARPROV) Banten menunjukkan keseriusan dalam sektor kepariwisataan.

Salah satu tujuan pengembangan kekayaan alam dan budaya daerah sebagai destinasi pariwisata adalah bentuk peningkatan devisa bagi daerah secara khusus dan perekonomian masyarakat lokal atau daerah pada umumnya. Namun demikian kebijakan dan strategi dalam pengembangan dan pengelolaan kepariwisataan daerah menjadi sesuatu yang harus diperhatikan sehingga tidak menimbulkan konflik antarmasyarakat maupun kegagalan dalam pengimplementasiannya. Potensi konflik dalam pengelolaan pariwisata menjadi salah satu penghambat pemngembangan kepariwisataan daerah. Oleh karena itu, sinergitas antar pihak menjadi elemen penting terwujudnya kepariwisataan di daerah. Penelitian Siti Soviah, dkk. (Soviah, Maulana, \& Nugroho, 2020:79) menyebutkan bahwa dalam pengelolaan pariwisata yang diperlukan adalah sinergitas antara para pihak yang harus berkolaborasi dalam mewujudkan pengembangan kepariwisataan antara lain pemerintah daerah, pihak swasta, serta masyarakat sekitar lokasi pariwisata.

Kota Cilegon dikenal dengan istilah Kota Industri sebagaimana fakta yang menunjukkan bahwa hampir seluruh wilayah pesisir Kota Cilegon dimanfaatkan sebagai lahan industri. Meskipun Kota Cilegon identik dengan industri, akan tetapi hampir sebagian besar wilayah Kota Cilegon merupakan daerah pegunungan dan perbukitan. Pegunungan dan perbukitan yang ada di Kota Cilegon memiliki potensi sumber daya alam yang dapat dijadikan sebagai obyek wisata. Potensi-potensi yang dimiliki Kota Cilegon tersebut memberikan pengaruh pada stakeholder dalam merumuskan kebijakan pemerintah daerah, sehingga melahirkan kebijakan kepariwisataan sebagai bagian dari visi dan misi Kota Cilegon. Oleh karena itu, melalui berbagai regulasi dirumuskan mengenai konsep dan zonasi (kawasan) pariwisata yang akan dikembangkan di Kota Cilegon.

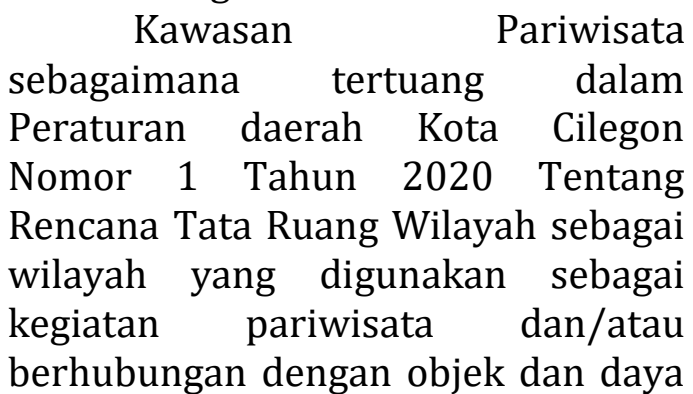


tarik wisata serta usaha-usaha yang berkaitan selama tidak mengganggu kelestarian budaya, keindahan alam dan lingkungan. Pengembangan pariwisata di Kota Cilegon merupakan salah satu program prioritas Pemerintah Daerah Kota Cilegon sebagai kota pusat jasa, kota perdagangan dan kota pariwisata berskala internasional. Oleh karena itu, potensi pariwisata dan budaya daerah di kota Cilegon terus ditingkatkan melalui berbagai sumber daya alam dan nilai budaya yang ada.

Pengembangan pariwisata di wilayah Kota Cilegon terus diupayakan melalui peningkatan Obyek Daya Tarik Wisata (ODTW). Beberapa jenis ODTW yang diupayakan Dinas Pariwisata dan Kebudayaan Kota Cilegon antara lain Wisata Tirta (Situ Rawa Arum), Wisata Agro (Watu Lawang; Gunung Batur), Wisata Religi (Makam Syekh Jamaludin), Wisata Industri, Wisata Bahari (Pulau Merak Besar; Pulau Merak Kecil), dan Wisata Kuliner. (Rencana Kerja Disparbud Kota Cilegon 2018 : 21) Kebijakan penetapan kawasan dan obyek wisata tersebut menunjukkan keinginan pemerintah daerah dalam mewujudkan kepariwisataan di Kota Cilegon.

Watu lawang merupakan destinasi agrowisata memiliki potensi wisata yang dapat dikembangkan sebagai salah satu obyek wisata di Kota Cilegon. Penetapan Watu Lawang sebagai agrowisata sebagaimana dimuat dalam Rencana Kerja Dinas Pariwisata Kota Cilegon Tahun 2018 merupakan bentuk dukungan dalam meningkatkan potensi sumber daya alam sebagai destinasi pariwisata. Penetapan agrowisata dengan latar belakang pedesaan dan pegunungan merupakan implementasi peraturan daerah kota Cilegon tentang rencana tata ruang wilayah dalam bentuk agrowisata dan kampung wisata dalam zonasi wisata yang berada dalam kawasan perumahan dan/atau pemukiman.

Namun demikian, potensi sumber daya alam yang dimiliki kawasan watu lawang yang terletak di Kelurahan Gerem Kecamatan Gerogol Kota Cilegon tersebut tidak menjadi obyek wisata yang dikelola secara profesional di bawah Dinas Pariwisata Dan Kebudayaan Kota Cilegon. Pengembangan kepariwisataan harus dilakukan secara bertahap dan berkesinambungan, sehingga semangat pembangunan dan eksplorasi kawasan dan sumber daya alam dapat dilakukan secara maksimal. Pemerintah daerah melalui dinas pariwisata dan kebudayaan perlu memiliki kebijakan dan strategi yang tepat dalam proyek pembangunan desa wisata dan/atau agrowisata.

Upaya pembangunan dan pengembangan destinasi wisata harus diselaraskan dengan kebijakan kepariwisataan nasional, kebijakan dan strategi pemerintah daerah dalam pembangunan dan pengembangan pariwisata daerah. Oleh karena itu, keberhasilan pembangunan kepariwisataan terletak pada kebijakan dan strategi pemerintah daerah dalam mengelola potensi alam yang dimiliki. Sektor pariwisata dapat menjadi salah satu kebijakan strategis pemerintah daerah dalam mendorong pertumbuhan sektor ekonomi bagi daerah dan menggerakkan ekonomi masyarakat lokal.

Pengembangan agrowisata Watu Lawang dapat memberikan dampak yang sangat luas, bukan hanya menjadi daya tarik atau obyek wisata semata. Akan tetapi 
pembangunan dan pengembangan obyek wisata Watu Lawang dapat meningkatkan ketenagakerjaan dan perekonomian lokal. Dengan adanya kebijakan kepariwisataan terhadap pembangunan dan pengembangan agrowisata akan berdampak pada peningkatan potensi-potensi lain yang menyertai pengembangan kepariwisataan.

Dampak pengembangan kepariwisataan pernah diteliti oleh Ahmad Sururi dalam penelitian pengembangan potensi dan dampak kepariwisataan bagi masyarakat lokal bahwa pariwisata memiliki dampak multisektoral, sehingga pengelolaan dan pengembangan sektor pariwisata perlu melibatkan berbagai pihak agar manfaatnya dapat dirasakan oleh semua pihak terutama masyarakat sekitar kawasan pariwisata. (Sururi, 2018:115) Oleh karena itu, kebijakan dan upaya pembangunan dan pengembangan desa wisata agro Watu Lawang, membutuhkan konsistensi kebijakan pemerintah daerah dalam mewujudkan pariwisata yang berimplikasi pada sektor-sektor lainnya baik sektor ekonomi maupun sektor ketenagakerjaan.

Keberadaan wisata agro pada suatu wilayah yang dikelola pemerintahan desa dan/atau kelurahan memberikan peluang peningkatan pertumbuhan perekonomian. Potensi yang dimiliki pemerintahan daerah harus dikelola secara efektif dan efisien melalui perumusan kebijakan dan tata kelola yang tepat. Tata kelola pemerintahan tingkat Desa dan/atau Kelurahan oleh Budi Hasanah diuraikan tentang konsepsi tata kelola desa yang mendiskusikan bahwa desa harus mampu mengelola desentralisasi fiskal melalui pengembangan potensi desa dan meningkatkan peran serta masyarakat dalam pembangunan desa. Sehingga dapat menciptakan peluang dalam menggerakkan perekonomian masyarakat lokal melalui upaya-upaya efektif dan strategis. (Hasanah, 2019:109)

Kebijakan yang dirumuskan
dan diimplementasikan oleh pemerintah daerah merupakan bentuk kebijakan publik yang pada dasarnya adalah suatu keputusan yang tersusun secara sistematis dan dimaksudkan untuk mengatasi permasalahan tertentu dan/atau untuk mencapai tujuan tertentu, yang dilaksanakan oleh lembaga/institusi yang diberikan berkewenangan dalam rangka penyelenggaraan tugas pemerintahan dan/atau pembangunan. (Kharisma, 2013:98) Upaya pencapaian tujuan yang ditetapkan pemerintah daerah melalui suatu kebijakan publik perlu mendapatkan kajian review dan monitoring yang didasarkan pada suatu analisis. Dalam kajian kebijakan publik, dibutuhkan suatu analisis kebijakan guna mentransformasikan suatu informasi yang relevan dengan kebijakan yang direncanakan, disusun dan diimplementasikan oleh pemerintah. Analisis kebijakan menurut Walter William dikemukakan sebagai suatu proses sintesis informasi untuk menghasilkan suatu alternatif kebijakan yang relevan. (Muriawan \& Lituhayu, 2017:9)

Dengan demikian, kebijakan pembangunan dan pengembangan pariwisata yang dilakukan oleh pemerintah daerah perlu mendapatkankan kajian analisis baik secara praktis maupun secara teoritis. Analisis kebijakan dimaksudkan untuk memperoleh data dan informasi yang relevan dalam upaya pembangunan dan pengembangan sektor pariwisata yang hendak dijadikan sebagai leading sector dalam upaya 
pembangunan perekonomian daerah. Strategi dan kebijakan yang dirumuskan pemerintah menunjukkan keseriusan dalam upaya pembangunan dan pengelolaan suatu tindakan pemerintah. Oleh karena itu, setiap kebijakan dan strategi yang dirumuskan perlu dilakukan analisis guna mengetahui sejauh mana keberhasilan dan/atau hambatan yang dihadapi dalam rangka mewujudkan tujuan yang ditetapkan dalam kebijakan.

\section{METODE PENELITIAN}

Metode yang digunakan dalam penelitian adalah model penelitian kualitatif analitis untuk menggambarkan fakta-fakta secara sistematis dan terintegrasi. Penelitian kualitatif mengarah pada eksplorasi suatu makna yang timbul dari dinamika sosial. (Creswell, 2015:4) Pendekatan yang digunakan peneliti adalah pendekatan yuridis normatif, yakni memadankan regulasi dan kebijakan dengan pelaksanaan teknis melalui strategi-strategi dan upayaupaya yang telah dilakukan. (Fuqoha, Firdausi, \& Sanjaya, 2019:78) Dalam penelitian ini, penulis menggunakan kajian literatur berupa buku dan jurnal hasil penelitian dan kajian konseptual serta artikel dalam surat kabar cetak dan digital/online. Pengumpulan dokumen dilakukan melalui observasi dan teknik wawancara menggunakan pendekatan purposive sampling. Wawancara dilakukan pada subjeksubjek pelaksana kebijakan dan pemangku kewenangan disesuaikan dengan objek penelitian.

\section{HASIL DAN DISKUSI}

\section{Strategi dan Kebijakan Pengembangan Pariwisata Di Kota Cilegon}

Peran pemerintah daerah dalam pengembangan pariwisata dalam kerangka desentralisasi menjadikan daerah sebagai pemangku kebijakan pengembangan yang bersinergi dengan kebijakan nasional dalam bidang kepariwisataan. Leading sector dalam pembangunan dan pengembangan destinasi pariwisata daerah menjadi tanggung jawab Dinas Pariwisata dan Kebudayaan. Sebagaimana tugas pokok dan fungsi Dinas Pariwisata dan Kebudayaan yang dibebankan tugas untuk mengeksplorasi potensi pariwisata dan nilai-nilai budaya daerah sebagai bagian dari percepatan perekonomian daerah dan masyarakat lokal melalui kepariwisataan.

Dalam satu kajian

kepariwisataan Riska Destiana, dkk. (Destiana, Kismartini, \& Yuningsih, 2020:138-142) menunjukkan analisa peran pemerintah daerah dan/atau stakeholder yang berwenang dalam pelaksanaan strategi pengembangan pariwisata diantaranya (1) Policy Creator, (2) Koordinator, (3) Fasilitator, (4) Implementor, dan (5) Akselerator. Pengembangan kepariwisataan sebagai salah satu sektor pembangunan nasional merupakan salah satu program prioritas Pemerintah Daerah Kota Cilegon yang tertuang dalam visi pemerintah daerah sebagai Kota Pusat Jasa, Kota Perdagangan dan Kota Pariwisata Berskala Internasional.

Strategi pengembangan pariwisata dalam unsur policy creator yakni Pemerintah Daerah melalui Dinas Pariwisata dan Kebudayaan sebagai pembuat kebijakan. Kebijakan menurut Carl J. Frederick diartikan sebagai serangkaian tindakan yang diusulkan seseorang, kelompok, atau pemerintah dalam suatu lingkungan tertentu dimana terdapat hambatan-hambatan dan 
kesempatan-kesempatan dalam implementasi kebijakan yang diusulkan dalam rangka mencapai tujuan yang ditetapkan. (Taufiqurakhman, 2014:2) Dengan demikian, Pemerintah Daerah sebagai pembuat kebijakan dalam bidang kepariwisataan perlu memperhatikan peluang dan hambatan yang dihadapi dalam pembangunan dan pengembangan kepariwisataan baik dalam bentuk regulasi maupun strategi implementasi. Diperlukan suatu inovasi dalam menyusun kerangka kebijakan yang akan ditempuh. Model inovasi kebijakan pariwisata perlu dilakukan melalui pendekatan dan sinergitas antarpemerintah, antara pemerintah dengan pihak swasta dan sinergitas masyarakat dengan stakeholder lainnya. Oleh karena itu, perlu regulasi yang mengatur batas-batas kewenangan dan intervensi antara pemerintah selaku regulator dan supervisor, swasta selaku fasilitator dan masyarakat/publik selaku operator. (Berthanila, Hasanah, \& Sururi, 2019:2) Penyusunan kebijakan publik dalam rangka pencapaian tujuan dan kepentingan pemerintah baik nasional maupun daerah perlu dimulai perumusan masalah publik sebagaimana konsep Sudarsono ke dalam 4 (empat) proses yakni pencarian masalah (problem search), pendefinisian masalah (problem definition), spesifikasi masalah (problem specification), dan pengenalan masalah (problem sensing). (Subarsono, 2016:29)

Peran pemerintah sebagai koordinator dan fasilitator menjadi variabel penting dalam terselenggaranya kebijakan yang dirumuskan oleh pemerintah. Pemerintah Daerah kota Cilegon sebagai koordinator harus mampu menggerakkan pelaksana kebijakan ke arah yang ditentukan dan menjadi arah tujuan kebijakannya. Selain menjadi pusat koordinasi dalam arah kebijakan, Disparbud kota Cilegon perlu memfasilitasi tercapainya kebijakan, regulasi maupun strategi yang dirumuskan. Fasilitasi dalam pembangunan dan pengembangan kepariwisataan dapat dilakukan bersama-sama dengan pihak swasta, sehingga tanggung jawab fasilitasi oleh pihak pemerintah tidak terlalu membebani anggaran. Setelah itu, peran pemerintah sebagai implementor dan akselerator terletak pada Dinas Pariwisata dan Kebudayaan yang melaksanakan regulasi dan strategi yang dirumuskan dalam tahapan teknis. Akselerasi juga dibutuhkan untuk mempercepat proses pembangunan dan pengembangan kepariwisataan sebagaimana model inovasi kebijakan.

Kebijakan kepariwisataan yang diselenggarakan oleh Dinas Pariwisata Kota Cilegon merujuk pada Peraturan Daerah Kota Cilegon Nomor 1 Tahun 2020 Tentang Rencana Tata Ruang Wilayah yang dimuat dalam Paragraph 6 Pasal 31 :

1) Kawasan pariwisata sebagaimana diatur dalam pasal 26 ayat (2) huruf e dengan luas kurang lebih 12 ha (dua belas hektar) meliputi

a. pembangunan daya tarik wisata;

b. penataan kawasan kegiatan usaha kepariwisataan;

2) Pembangunan daya tarik wisata yang dimaksud dalam ayat (1) huruf a, diatur lebih lanjut dalam RIPPDA Kota Cilegon;

3) Penataan kawasan kegiatan usaha kepariwisataan sebagaimana dimaksud ayat (1) huruf $b$ berupa penataan kawasan hiburan pada wilayah yang diperuntukan bagi perdagangan dan jasa diatur 
lebih lanjut dalam Rencana Induk Pengembangan Pariwisata Daerah (RIPPDA) Kota Cilegon;

4) Rencana Kawasan Pariwisata sebagaimana dimaksud pada ayat (1) digambarkan dalam peta dengan tingkat ketelitian 1:25.000 sebagaimana tercantum dalam lampiran XXI Peraturan Daerah ini.

Pembangunan pariwisata di daerah harus dimulai dengan harmonisasi hubungan pemerintah dengan masyarakat lokal, mengevaluasi potensi sumber daya alam dan/atau budaya lokal, dan adanya review peminatan wisatawan. Sebagaimana diuraikan Budi Hasanah (Hasanah, 2019:112) dalam kajian desa wisata yaitu Peningkatan antusiasme masyarakat melalui pembentukan suatu wadah organisasi sebagai penggerak, melalui kolaborasi pemerintah dan masyarakat lokal; Memberikan dukungan keberlanjutan lingkungan fisik, melalui peningkatan sumber daya manusia, akses serta potensi sumber daya alam maupun kebudayaan; Adanya dukungan keberlanjutan dalam bidang perekonomian melalui peningkatan pemasaran hasil-hasil ekonomi kreatif masyarakat; Membangun jaringan dan sistem informasi yang dapat digunakan bersama-sama pemerintah dan masyarakat; dan Menjaga pelayanan bagi kepuasan wisatawan, pengadaan informasi yang efektif, serta mengutamakan kenyamanan bagi wisatawan.

$\begin{array}{cr}\text { Kawasan } & \text { Pariwisata } \\ \text { sebagaimana tertuang dalam }\end{array}$

Peraturan Daerah (PERDA) Kota Cilegon Nomor 1 Tahun 2020 Tentang Rencana Tata Ruang Wilayah sebagai wilayah yang digunakan sebagai kegiatan pariwisata dan/atau berhubungan dengan objek dan daya tarik wisata serta usaha-usaha yang berkaitan selama tidak mengganggu kelestarian budaya, keindahan alam dan lingkungan. Konsepsi kepariwisataan daerah Kota Cilegon merupakan implementasi dari kebijakan nasional mengenai kepariwisataan yang dituangkan dalam Peraturan Pemerintah (PP) Nomor 50 Tahun 2011 Tentang Rencana Induk Pembangunan Kepariwisataan Nasional Tahun 2010-2025. Kebijakan dan strategi yang dilakukan pemerintah kota Cilegon dengan dibentuknya kajian wilayah strategis sebagai Obyek Daya Tarik Wisata (ODTW).

Pengembangan pariwisata di wilayah Kota Cilegon terus diupayakan melalui peningkatan Obyek Daya Tarik Wisata (ODTW). Beberapa jenis ODTW yang diupayakan Dinas Pariwisata dan Kebudayaan Kota Cilegon antara lain Wisata Tirta (Situ Rawa Arum), Wisata Agro (Watu Lawang; Gunung Batur), Wisata Religi (Makam Syekh Jamaludin), Wisata Industri, Wisata Bahari (Pulau Merak Besar; Pulau Merak Kecil), dan Wisata Kuliner. (Rencana Kerja Disparbud Kota Cilegon $2018: 21$ )

Arah kebijakan pembangunan dan pengembangan Obyek Daya Tarik Wisata (ODTW) yang diupayakan Dinas Pariwisata dan Kebudayaan kota Cilegon merupakan implementasi kebijakan nasional dari PP Nomor 50 Tahun 2011 dalam Pasal 8 bahwa pembangunan destinasi pariwisata nasional (DPN) meliputi:
a. Perwilayahan Pembangunan DPN;
b. Pembangunan Daya Tarik Wisata;
c. Pembangunan Aksesibilitas Pariwisata;
d. Pembangunan Prasarana Umum, Fasilitas Umum dan Fasilitas Pariwisata; 
e. Pemberdayaan Masyarakat melalui Kepariwisataan; dan

f. Pengembangan Investasi di Bidang Pariwisata.

Strategi dalam implementasi kebijakan tersebut dijelaskan pada Bagian Ketiga mengenai Pembangunan Daya Tarik Wisata yang dituangkan dalam Pasal 14 ayat 1 bahwa pembangunan daya tarik wisata dapat meliputi daya tarik wisata alam, daya tarik wisata budaya dan daya tarik wisata hasil buatan manusia. Upaya implementasi strategi dan arah kebijakan pembangunan kepariwisataan dapat dilakukan dengan beberapa instrumen sebagaimana dituangkan dalam Pasal 15 sebagai berikut:

a. Perintisan pengembangan daya tarik wisata dalam rangka mendorong pertumbuhan DPN dan pengembangang daerah;

b. Pembangunan daya tarik wisata untuk meningkatkan kualitas dan daya saing produk dalam menarik minat dan loyalitas segmen pasar yang ada;

c. pemantapan daya tarik wisata untuk meningkatkan daya saing produk dalam menarik kunjungan ulang wisatawan dan segmen pasar yang lebih luas; dan

d. revitalisasi daya tarik wisata dalam upaya peningkatan kualitas, keberlanjutan dan dan daya saing produk DPN.

Kebijakan pembangunan dan pengembangan kepariwisataan nasional ditindaklanjuti oleh pemerintah daerah melalui Rencana Induk Pengembangan Kepariwisataan Provinsi (RIPPARPROV) sebagaimana dituangkan dalam Peraturan Daerah Provinsi Banten Nomor 6 Tahun 2019 Tahun Rencana Induk Pengembangan Kepariwisataan Provinsi Banten Tahun 2018-2025. Dalam regulasi dan/atau kebijakan daerah tersebut disebutkan arah kebijakan pengembangan pariwisata sebagaimana tertuang dalam Pasal 7 bahwa arah kebijakan, strategi, dan indikasi program pembangunan kepariwisataan Provinsi Banten dalam kurun waktu tahun 2018 sampai dengan tahun 2025 yang meliputi pembangunan: Destinasi pariwisata provinsi, pemasaran pariwisata provinsi, industri pariwisata provinsi, dan kelembagaan kepariwisataan provinsi.

Keberadaan suatu regulasi dan strategi yang disusun menjadi elemen penting dalam mewujudkan keberhasilan pemerintah dan stakeholder di bidang kepariwisataan. Oleh karena itu, peran dan kedudukan kebijakan dalam tercapainya keberhasilan pariwisata nasional dan daerah dapat diukur dan dievaluasi. Kebijakan dan strategi menjadi langkah penting dalam ketercapaian tujuan pemerintahan baik pusat maupun daerah. Selain itu, kebijakan dan strategi juga menjadi tolak ukur dalam merumuskan kebijakan dan strategi di masa yang akan datang. Oleh karena itu, Pemerintah Daerah Kota Cilegon dan Dinas Pariwisata dan Kebudayaan Kota Cilegon membutuhkan landasan hukum (regulasi) dan/atau kebijakan kepariwisataan sebagaimana diatur mekanismenya melalui Rencana Induk Pengembangan Kepariwisataan. Dengan adanya Rencana Induk Pengembangan Kepariwisataan Daerah (RIPPDA), maka arah kebijakan dan strategi akan dapat diimplementasikan dan dapat dianalisis dalam rangka ketercapaian kebijakan kepariwisataan daerah. 


\section{Analisis Potensi Wisata Agro Watu Lawang Terhadap Peningkatan Daerah dan Ekonomi Masyarakat}

Peningkatan daya saing kepariwisataan di daerah perlu memperhatikan peluang dan kendala yang dimiliki daerah dalam menetapkan zona dan/atau destinasi wisata. Potensi kekhasan yang dimiliki suatu daerah memberikan peluang dalam menggerakkan wisatawan lokal, nasional maupun mancanegara. Oleh karena itu, setiap potensi dan kendala yang ada perlu mendapatkan perhatian dan analisis kebijakan pengembangan kepariwisataan. Potensi kepariwisataan daerah maupun nasional memiliki peranan penting dalam perekonomian daerah maupun nasional. Hal tersebut merujuk pada daya beli wisatawan yang memberikan sumber penghasilan bagi masyarakat lokal maupun pendapatan bagi pemerintah daerah. Pengembangan kawasan pariwisata tidak dapat dilepaskan dari peran pemerintah daerah, masyarakat lokal hingga peran pihak swasta yang berinisiasi dan bersinergi untuk membangun daya tarik wisata. Sebagaimana dituangkan dalam Peraturan Daerah (PERDA) Kota Cilegon Tentang Rencana Tata Ruang Wilayah bahwa perlu adanya pembangunan dan pengembangan obyek wisata sehingga memiliki daya tarik wisata. Pengembangan kepariwisataan di wilayah Kota Cilegon terus diupayakan melalui program peningkatan Obyek Daya Tarik Wisata (ODTW).

Potensi Wisata Agro Watu Lawang yang terletak di Kelurahan Gerem, Kecamatan Gerogol, Kota Cilegon merupakan salah satu destinasi wisata yang berasal dari sumber daya alam. Watu Lawang merupakan daerah pegunungan yang dapat dijadikan salah satu destinasi wisata bagi masyarakat yang hendak merasakan suasana pegunungan dan alam di Kota Cilegon. Hal tersebut dapat menjadi potensi, mengingat Kota Cilegon merupakan kota industri yang menunjukkan kondisi alam dan wilayah Kota Cilegon dipenuhi dengan polusi dan pencemaran udara maupun alam.

Kekayaan alam dan budaya yang dimiliki daerah, khususnya daerah wisata agro Watu Lawang di Kelurahan Gerem dapat diberdayakan sebagai salah satu destinasi wisata untuk mendukung pengembangan kepariwisataan daerah serta peningkatan potensi perekonomian masyarakat lokal. Namun demikian, penetapan wisata agro Watu Lawang perlu memperhatikan kebijakan daerah dalam pengembangan daerah wisata dengan memperhatikan peluang dan kendala. Dalam Rencana Strategis Pengembangan Destinasi dan Industri Pariwisata Tahun 2015-2019 menguraikan beberapa peluang dan kendala yang dihadapi dalam pembangunan dan pengembangan kepariwisataan yang diurai dalam tabel berikut : 
Tabel 1

Peluang dan Kendala Kepariwisataan

\begin{tabular}{|rl}
\hline PELUANG \\
\hline 1. & Sumber Daya Alam \\
2. Prioritas Kepariwisataan \\
3. Daya Saing Harga \\
4. Sumber Daya Manusia \\
5. Keselamatan dan Keamanan
\end{tabular}
KENDALA

1. Infrastruktur Pariwisata

2. Infrastruktur ICT

3. Kebersihan dan Kesehatan

4. Aksesibilitas (Connectivity, Seat Capacity, dan Direct Flight)

5. Regulasi (Izin Masuk Kapal Layar/Yacht, Visa, dan Bea Cukai)

Sumber : Rencana Strategis Kemenparekraf 2015-2019, hal. 20

Upaya pembangunan dan pengembangan Watu Lawang sebagai Wisata Agro sebagai destinasi kepariwisataan daerah Kota Cilegon sangat berpotensi untuk dikembangkan. Dari segi peluang sumber daya alam, prioritas kepariwisataan, daya saing harga, sumber daya manusia dan keselamatan dan keamanan yang dapat dikembangkan. Menurut penjelasan Kepala Kelurahan Gerem, Kecamatan Gerogol Kota Cilegon bahwa Watu Lawang sangat berpotensi dijadikan sebagai obyek pariwisata yang dilihat dari sumber daya alam yang sangat alami. Dari sisi kebijakan daerah bahwa obyek wisata Watu Lawang merupakan salah satu prioritas pariwisata kelurahan Gerem yang hendak dikembangkan bersama-sama obyek lainnya yaitu Kampung Wisata Cikuasa, Wisata Agro Watu Lawang dan Pemanfaatan Galian C menjadi obyek Wisata Kuliner. (Wawancara, Deni Yuliandi)

Daya saing harga, sumber daya manusia hingga keselamatan dan keamanan dapat terus diberdayakan sehingga dapat mengeksplorasi potensi alam dan sumber daya manusia dalam rangka pengembangan Agrowisata Watu Lawang. Deni Yuliandi menguraikan bahwa telah ada Kelompok Sadar Wisata (POKDARWIS) di Kelurahan Gerem yang dapat dioptimalkan. Pokdarwis yang ada merupakan bagian dari Kampung Wisata Cikuasa, akan tetapi dapat dioptimalkan perannya berskala wilayah kelurahan. (Wawancara, Deni Yuliandi)

Pengembangan Watu Lawang sebagai destinasi Agrowisata di Kota Cilegon belum dilakukan secara maksimal. Upaya pengembangan baru dilakukan secara swadaya masyarakat untuk mengeksplorasi potensi alam yang dimiliki warga sekitar lokasi Agrowisata Watu Lawang. Oleh karena itu, potensi alam yang ada tidak dapat dimaksimalkan sebagai destinasi wisata agro di Kelurahan Gerem maupun sebagai Obyek Wisata Unggulan di Kota Cilegon. 
Gambar 1

Tugu Selamat Datang dan Akses Jalan
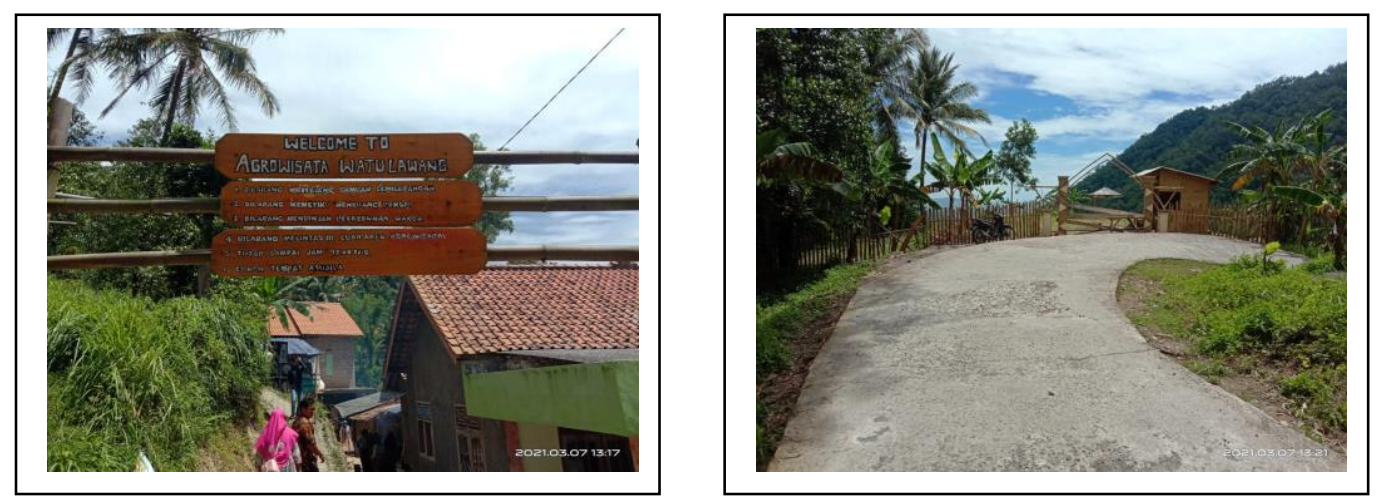

Pembangunan

dan pengembangan wisata Watu Lawang sebagai salah satu obyek wisata yang potensial memiliki kendala. Persoalan kebersihan dan kesehatan menjadi salah satu faktor yang menjadi kendala pengembangan destinasi agrowisata. Dijelaskan oleh Kepala Kelurahan Deni Yuliandi, wilayah Watu Lawang merupakan salah satu wilayah yang sangat kesulitan mendapatkan air bersih sepanjang tahun baik di musim penghujan dan terlebih di musim kemarau. Sedangkan salah satu fasilitas yang perlu dimiliki oleh obyek wisata adalah sarana dan prasarana yang meliputi air, toilet dan mushola. Dengan demikian, upaya yang selama dilakukan adalah menjalin kerja sama dengan berbagai pihak baik pemerintah daerah maupun bekerja sama dengan pihak swasta dalam memecahkan persoalan tersebut.

Upaya pembangunan dan pengembangan sektor pariwisata di wilayah Watu Lawang sebagai
Agrowisata diharapkan mampu menggerakkan perekonomian masyarakat lokal. Nilai-nilai budaya dan sumber daya manusia yang ada diharapkan mampu memberikan kesejahteraan bagi masyarakat lokal. Salah satu makanan khas yang diharapkan mampu menggerakkan ekonomi masyarakat lokal adalah Tape Ketan khas Gerem dan Emping. Dengan demikian, bukan sekedar eksplorasi alam yang dijadikan kepariwisataan tetapi juga potensi budaya dan kewirausahaan masyarakat lokal.

\section{Pemerintah Daerah Kota} Cilegon melalui Dinas Pariwisata dan Kebudayaan menetapkan Watu Lawang kedalam Rencana Kerja Pengembangan Pariwisata Kota Cilegon 2018. Dengan demikian, obyek wisata agro Watu Lawang menjadi prioritas pembangunan dan pengembangan pariwisata Pemerintah Daerah Kota Cilegon, sebagaimana tercantum dalam tabel berikut ini : 
Tabel 2

Pembangunan dan Pengembangan Obyek daya Tarik Wisata Kota Cilegon

\begin{tabular}{|c|c|c|}
\hline Jenis ODTW & $\begin{array}{c}\text { ODTW Yang } \\
\text { Dikembangkan }\end{array}$ & Tahun Pembuatan \\
\hline $\begin{array}{l}\text { 1. Wisata Tirta : } \\
\text { a.Situ Rawa Arum }\end{array}$ & Site Plan Situ Rawa Arum & Tahun 2010 \\
\hline $\begin{array}{l}\text { 2. Wisata Agro: } \\
\text { a. Watu Lawang } \\
\text { b.Gunung Batur }\end{array}$ & $\begin{array}{l}\text { Feasibility (FS), dan } \\
\text { Perencanaan Teknis Watu } \\
\text { Lawang } \\
\text { Feasibility Study (FS) } \\
\text { Gunung Batur }\end{array}$ & $\begin{array}{l}\text { Tahun } 2013 \\
\text { Tahun } 2016\end{array}$ \\
\hline $\begin{array}{l}\text { 3. Wisata Budaya/ } \\
\text { Religi/Sejarah }\end{array}$ & $\begin{array}{l}\text { Penataan Obyek Religi } \\
\text { (Makam Syekh Jamaludin) }\end{array}$ & Tahun 2015 \\
\hline 4. Wisata Industri & Promosi Wisata Industri & Tahun 2014 \\
\hline 5. Wisata Bahari & $\begin{array}{l}\text { Pulau Merak Besar dan } \\
\text { Pulau Merak Kecil }\end{array}$ & \\
\hline 6. Wisata Kuliner & $\begin{array}{l}\text { Kajian Teknis Tentang } \\
\text { Wisata Kuliner } \\
\text { Penataan Wisata Kuliner } \\
\text { Penataan Wisata Kuliner } \\
\text { Lanjutan }\end{array}$ & $\begin{array}{l}\text { Tahun } 2013 \\
\text { Tahun } 2014 \\
\text { Tahun } 2015\end{array}$ \\
\hline
\end{tabular}

Sumber : Rencana Kerja Dinas Pariwisata dan Kebudayaan Kota Cilegon 2018, hal. 21

Upaya pembangunan dan pengembangan agrowisata Watu Lawang telah dicanangkan sejak tahun 2013. Dengan demikian, peran pemerintah dalam meningkatkan kepariwisataan Kota Cilegon dirumuskan dalam suatu kebijakan perencanaan yang disusun dalam Rencana Kerja (Renja) tahunan sebagaimana dituangkan dalam Renja Disparbud Kota Cilegon 2018. Pengembangan Agrowisata Watu Lawang menurut penjelasan Dinas Pariwisata dan Kebudayaan Kota Cilegon yang disampaikan oleh Kepala Bidang Pariwisata memiliki potensi yang luar biasa karena lahir dari alam dan bukan buatan. Oleh karena itu, Disparbud Kota Cilegon memiliki visi ke depan mengoptimalkan potensi alam yang ada di Kota Cilegon selain industri. Industri di Cilegon tidak dapat dihindarkan karena secara geografis yang memiliki wilayah pesisir menjadi potensi industri yang sangat besar. (Wawancara, Mamat Slamat) Implementasi Rencana Kerja Pemerintah Daerah Kota Cilegon melalui Disparbud Kota Cilegon tersebut semestinya dapat merujuk pada PP Nomor 50 Tahun 2011 dalam Pasal 14, Pasal 15 dan Pasal 16 yang mengkaji mengenai Pembangunan Daya Tarik Wisata. Strategi yang dapat dilakukan sebagaimana dijelaskan dalam Pasal 16 antara lain :

a. Memperkuat upaya pengelolaan potensi kepariwisataan;

b. Mengembangkan inovasi manajemen produk dan kapasitas daya tarik wisata;

c. memperkuat upaya konservasi potensi kepariwisataan dan lingkungan; 
d. Mengembangkan diversifikasi atau keragaman nilai daya tarik wisata;

e. memperkuat upaya penataan ruang wilayah dan konservasi potensi kepariwisataan dan lingkungan; dan

f. Revitalisasi struktur, elemen dan aktivitas yang menjadi penggerak kepariwisataan.

Potensi alam yang dimiliki Pemerintah Daerah Kota Cilegon, salah satunya adalah obyek wisata Watu Lawang yang diharapkan menjadi obyek Wisata Agro kota Cilegon. Hal tersebut sebagaimana telah diupayakan dalam Renja Tahun 2018. Persoalan yang dihadapi oleh pemerintah daerah adalah adanya perubahan-perubahan kebijakan yang dikeluarkan Pemerintah Daerah Kota Cilegon baik dalam Keputusan Wali Kota maupun Regulasi yang dikeluarkan oleh legislatif (Dewan Perwakilan Rakyat Daerah Kota Cilegon). Salah satu diantaranya yakni perubahan dalam Rencana Tata Ruang Wilayah Kota Cilegon dalam Peraturan Daerah Nomor 1 Tahun 2020.

Implikasi dari perubahan kebijakan adalah perumusan ulang program dan rencana kerja yang telah disusun dan diimplementasikan. Dengan demikian, Disparbud Kota Cilegon menguraikan pembangunan dan pengembangan kepariwisataan melalui Rencana Induk Pembangunan Pariwisata Daerah (RIPPDA) Kota Cilegon. Penetapan Watu Lawang oleh Disparbud Kota Cilegon sebagai salah satu Wisata Agro didasarkan pada observasi dan kajian analisis bidang pariwisata. Dijelaskan Mamat Slamat bahwa banyak faktor yang mempengaruhi terhambatnya pengembangan Wisata Agro Watu Lawang antara lain letak geografis, sumber daya manusia, dan sosiologis.
Letak geografis Watu Lawang merupakan bagian dari Kelurahan Gerem, yang berada pada tapal batas antara Kota Cilegon dan Bojonegara Kabupaten Serang. Faktor geografis menjadi kendala tersendiri berkaitan dengan pengaruh masyarakat lokal yang nantinya akan dilibatkan dalam pengembangan dan eksplorasi obyek Watu Lawang. Sumber daya manusia yang didominasi petani menjadi salah satu kendala dalam menggerakkan pengembangan obyek wisata, disamping sebagian wilayah yang akan dijadikan obyek wisata masih menjadi milik warga yang dijadikan lahan pertanian. Faktor sosiologis masyarakat yang menunjukkan egosentris kewilayahan dianggap menjadi potensi konflik yang perlu dibenahi melalui pendekatan sosialisasi, kebersamaan dalam visi dan misi sampai dengan pembentukan Kelompok Sadar Wisata (Pokdarwis) di wilayah Watu Lawang. (Wawancara, Mamat Slamat).

Perumusan kebijakan dan strategi yang dirumuskan dalam regulasi daerah maupun kebijakan yang direkomendasikan Disparbud kota Cilegon belum dapat diimplementasikan. Oleh karena itu, kebijakan dan strategi yang disusun tidak dapat dievaluasi. Mazmanian dan Sabatier menguraikan variabel yang mempengaruhi implementasi kebijakan antara lain karakteristik masalah, karakteristik kebijakan/regulasi, dan variabel lingkungan. (Subarsono, 2016:94) Dari penjelasan Mazmanian dan Sabatier tersebut dapat dilihat bahwa setiap kebijakan yang disusun perlu dirumuskan berdasarkan pada permasalahan yang dihadapi oleh obyek wisata baik dari segi sumber daya manusia, sosiologis, geografis hingga ekonomi dan politik. Kebijakan dalam bentuk regulasi 
harus disusun berdasarkan pada karakteristik wilayah dan masyarakat daerah. Terakhir berkaitan persoalan lingkungan sebagai bagian dari suksesnya suatu kebijakan diimplementasikan.

Upaya Disparbud kota Cilegon dalam pengembangan Obyek Wisata Watu Lawang sebagaimana hasil observasi merupakan bentuk implementasi kebijakan nasional dalam strategi pembangunan daya tarik wisata dengan memperkuat upaya pengelolaan potensi kepariwisataan yang dimiliki obyek Wisata Watu Lawang Kelurahan Gerem hingga upaya revitalisasi struktur, elemen dan aktivitas yang menjadi penggerak kepariwisataan. Kedua hal tersebut menjadi landasan dasar dalam mewujudkan pembangunan dan pengembangan obyek wisata Watu Lawang sebagai destinasi wisata agro di kota Cilegon.

Kajian analisis yang dilakukan terhadap obyek wisata Watu Lawang membuat Disparbud Kota Cilegon mengalihkan prioritas pengembangan pariwisata pada destinasi wisata yang lain seperti Kampung Wisata Tani Cikuasa, Kampung Lukis Citangkil, dan Kampung Wisata Ternak Cikerai. Menurut Disparbud Kota Cilegon hal tersebut didasarkan pada peran pemerintah daerah dan masyarakat setempat dalam membentuk kepariwisataan secara bersamasama. Sinergitas dalam pembangunan dan pengembangan pariwisata antara pemerintah dan masyarakat setempat harus terbentuk sehingga proses pengembangan dan pengelolaan wisata dapat dioptimalkan dan meminimalisir potensi konflik pemerintah, masyarakat lokal terlebih bila ada peran swasta dalam pembangunan dan pengembangan obyek wisata.
Berdasarkan pada hasil penelitian yang dilakukan dalam analisis kebijakan pariwisata, bahwa dalam implementasi kebijakan dilihat melalui karakteristik masalah, karakteristik kebijakan/regulasi, dan variabel lingkungan. Pertama, dilihat dalam perspektif karakteristik permasalahan yaitu persoalan yang dihadapi oleh pemerintah daerah baik institusi pariwisata (Disparbud Kota Cilegon) maupun Pemerintah Kelurahan terletak pada pemenuhan sarana dan prasarana, sumber daya manusia yang terbatas hingga persoalan geografis. Kedua, pada tahapan kebijakan dan/atau regulasi bahwa kebijakan Pemerintah Daerah Kota Cilegon yang berubah seiring perubahan Rencana Tata Ruang Wilayah (RTRW) yang ditetapkan pemerintah daerah serta penyusunan Rencana Induk Pengembangan Pariwisata Daerah (RIPPDA) yang belum dapat dilaksanakan oleh institusi menjadi persoalan klasik penyelenggara negara. Hal tersebut berdampak pada berhentinya hingga tidak berjalannya program kerja yang telah disusun dan direncanakan. Ketiga, dilihat dari variabel lingkungan dimana kondisi lingkungan dipengaruhi faktor sosiologis yang dapat mempengaruhi keberhasilan suatu kebijakan. Sosiologis masyarakat lokal yang yang tidak sejalan dengan kepentingan pemerintahan mengakibatkan upaya dan strategi tidak dapat diimplementasikan.

Dalam suatu kajian kebijakan pengembangan lingkungan dan kepariwisataan terdapat beberapa langkah strategis diantaranya, kebijakan kendali dan kontrol, regulasi/peraturan, sukarelawan, dan pendidikan dan informasi. (Irwansyah, 2017:36) Didasarkan pada konsepsi tersebut, kebijakan penetapan agrowisata Watu Lawang 
oleh Pemerintah Daerah Kota Cilegon baik melalui Dinas Pariwisata maupun Pemerintah Kelurahan belum melaksanakan kebijakan pengendalian dan kontrol terhadap pembangunan dan pengembangan sebagai obyek wisata. Selain itu, regulasi pembangunan dan pengembangan kepariwisataan yang belum dilaksanakan dengan kendala belum disahkannya kerangka kepariwisataan daerah dalam RIPPDA mengakibatkan instansi/dinas pariwisata tidak dapat menjalankan rencana pengembangan. Persoalan lain yang menghambat adalah kesadaran masyarakat terhadap pariwisata hingga pendidikan dan informasi dalam pengembangan pariwisata yang belum terbentuk pada masyarakat, khususnya masyarakat lokal. Konsep sukarelawan dapat dibentuk melalui Kelompok Sadar Wisata (POKDARWIS) yang dapat membantu pemerintah dalam sosialisasi dan mengedukasi warga masyarakat dalam pengembangan hingga pengelolaan kepariwisataan. Wartiningsih dan Nunuk Nuswardani mengemukakan bahwa setiap implementasi kebijakan dan/atau regulasi pasti memiliki permasalahan, sehingga dibutuhkan pendekatan kebijakan (analisis kebijakan) serta kajian perbandingan (studi banding) untuk memetakan dan mendapatkan alternatif lain dalam implementasi. (Wartiningsih \& Nuswardani, 2021:130) Oleh karena itu, pemerintah daerah melalui dinas pariwisata maupun pemerintah desa/kelurahan mesti menyusun strategi dan upaya lain sebagai alternatif

\section{KESIMPULAN}

Kebijakan pemerintah yang menempatkan pariwisata sebagai leading sector dalam pembangunan dan peningkatan perekonomian nasional perlu mendapatkan dukungan dari semua pihak, baik pemerintah pusat, pemerintah daerah, pihak swasta hingga masyarakat. Terwujudnya kepariwisataan nasional dan daerah memberikan nilai-nilai kemanfaatan bukan hanya sekedar peningkatan destinasi dan obyek wisata, akan tetapi memberikan dampak pada peningkatan pendapatan daerah hingga mampu menggerakan ekonomi masyarakat lokal. Kebijakan dan strategi kepariwisataan telah dikeluarkan oleh pemerintah baik kebijakan nasional maupun kebijakan daerah, melalui institusi yang diberikan kewenangan di dalam bidang kepariwisataan. Pemerintah telah mengeluarkan kebijakan dan strategi pengembangan pariwisata melalui Undang-Undang hingga Peraturan Pemerintah. Kemudian Kementerian Pariwisata melakukan kajian dan menyusun Rencana Strategis dalam pembangunan dan pengembangan sektor kepariwisataan. Pemerintah daerah kota Cilegon membuat kebijakan yang tersusun dalam Peraturan Daerah dalam Rencana Tata Ruang Wilayah serta melalui Rencana Induk Pembangunan Pariwisata daerah yang disusun oleh Dinas Pariwisata dan Kebudayaan Kota Cilegon.

Dalam rangka mewujudkan Obyek Wisata Agro Watu Lawang dibutuhkan berbagai rencana dan strategi yang perlu dilakukan oleh semua pihak, mulai dari peningkatan aksesibilitas, fasilitas serta kerja sama antar pihak. Selain itu, perlu adanya peningkatan sumber daya manusia di masyarakat lokal guna mendukung pengembangan dan pengelolaan obyek wisata serta peningkatan kapabilitas dan sinergitas antar sektor baik dinas pariwisata, pemerintahan 
desa/kelurahan serta masyarakat dimana obyek wisata watu lawang akan dijadikan sebagai destinasi wisata daerah.

Saran dan rekomendasi peneliti dalam pengembangan Wisata Agro Watu Lawang Pertama melalui pendidikan kepariwisataan, banyak pihak khususnya masyarakat lokal yang belum mengetahui dan memahami pengaruh pembangunan dan pengembangan kepariwisataan yang dapat mempengaruhi dan meningkatkan sektor perekonomian masyarakat. Kedua pembentukan Kelompok Sadar Wisata (POKDARWIS), dengan mengoptimalisasi kelompok sadar wisata menjadi langkah pertama dalam upaya revitalisasi struktur, elemen dan aktivitas yang menjadi penggerak kepariwisataan.

\section{PENGHARGAAN}

Kami ucapkan terima kasih atas bantuan serta waktu yang diberikan dalam proses penelitian ini kepada (1) Bapak Mamat Slamat, S.Sos., M.M selaku Kepala Bidang Pariwisata Dinas Pariwisata dan kebudayaan Kota Cilegon, (2) Bapak Deni Yuliandi, S.E., M.M selaku Kepala Kelurahan Gerem, Gerogol, Kota Cilegon.

\section{REFERENSI}

\section{Jurnal}

Berthanila, R., Hasanah, B., \& Sururi, A. (2019). Kapasitas Inovasi Kebijakan Pemerintah Daerah Dalam Pengelolaan Kawasan Wisata Alam Gunung Pinang Kabupaten Serang. KNIA : Konferensi Nasional Ilmu Administrasi 4.0, 3(1), 1-6. Retrieved from http://180.250.247.102/confer ence/index.php/knia/article/vi ew/29
Destiana, R., Kismartini, K., \& Yuningsih, T. (2020). Analisis Peran Stakeholders Dalam Pengembangan Destinasi Pariwisata Halal Di Pulau Penyengat Provinsi Kepulauan Riau. Jurnal Ilmu Administrasi Negara ASIAN (Asosiasi Ilmuwan Administrasi Negara), 8(2), 132-153.

https://doi.org/10.47828/jiana asian.v8i2.18

Fuqoha, F., Firdausi, I. A., \& Sanjaya, A. E. (2019). Perlindungan Hukum Terhadap Intervensi Pemberitaan dalam Kerangka Kemerdekaan Pers Nasional. Ajudikasi: Jurnal Ilmu Hukum, 3(1), 75. https://doi.org/10.30656/ajudi kasi.v3i1.1436

Hasanah, B. (2019). Tata Kelola Desa Wisata Sukaratu Berbasis Kerakyatan. Sawala: Jurnal Administrasi Negara, 7(2), 108. https://doi.org/10.30656/sawa la.v7i2.1786

Irwansyah, I. (2017). Research-Based Environmental Law: the Debate Between Ecology Versus Development. Sriwijaya Law Review, 1(1), 044. https://doi.org/10.28946/slrev. vol1.iss1.8.pp044-066

Kharisma, B. (2013). EVALUASI PROGRAM - PROGRAM STRATEGIS PEMERINTAH KOTA BANDUNG DI BIDANG EKONOMI DALAM UPAYA PENGUATAN DAN PENINGKATAN KEMAMPUAN DAYA BELI MASYARAKAT : SUATU TINJAUAN ANALISIS KEBIJAKAN PUBLIK. Journal Theory and Applied Management, $6(3)$. https://doi.org/http://dx.doi.or g/10.20473/jmtt.v6i3.2672

Muriawan, F. R., \& Lituhayu, D. (2017). Analisis Pelaksanaan 
Kebijakan Kerjasama Antar Daerah Wilayah Kedungsepur Bidang Pariwisata. Indonesian Journal of Public Policy and Management Review, 6(0), 7. https://doi.org/https://doi.org /10.14710/jppmr.v6i2.14851

Soviah, S., Maulana, D., \& Nugroho, A. (2020). Tata Kelola Pengelolaan Pariwisata Di Kawasan Ekonomi Khusus Tanjung Lesung. Administratio: Jurnal Ilmiah Administrasi Publik Dan Pembangunan, 11(2), 79-90. https://doi.org/https://doi.org /10.23960/administratio.v11i2. 154

Sururi, A. (2018). Inovasi Kebijakan Partisipasi Publik Dalam Pengelolaan Dan Pengembangan Pariwisata (Studi Pada Kawasan Ekowisata Situterate Desa Situterate Kecamatan Cikande Kabupaten Serang). Jurnal Administrative Reform, 6(3), 110-121. https://doi.org/http://dx.doi.or g/10.30872/jar.v6i3.1905

Wartiningsih, W., \& Nuswardani, N. (2021). Policy Model Reconstruction of Social Forestry. Sriwijaya Law Review, 5(1), 130-142. https://doi.org/10.28946/slrev. Vol5.Iss1.

\section{Buku :}

Creswell, J. W. (2015). Research Design, Pendekatan Kualitatif, Kuantitatif dan Mixed (Third Ed.). Yogyakarta: Pustaka Pelajar.

Subarsono, A. (2016). Analisis Kebijakan Publik: Konsep, Teori dan Aplikasi (VIII). Yogyakarta: Pustaka Pelajar.

Sunarno, S. (2012). Hukum Pemerintahan Daerah di Indonesia (Cet. 4). Jakarta: Sinar Grafika.

Taufiqurakhman, T. (2014).
Kebijakan Publik: Pendelegasian Tanggungjawab Negara Kepada Presiden Selaku Penyelenggara Pemerintahan (1st ed.). Jakarta Pusat: FISIP - UNIVERSITAS MOESTOPO BERAGAMA PRESS.

\section{Perundang-Undangan}

Undang-Undang Republik Indonesia Nomor 10 tahun 2009 Tentang Kepariwisataan

Peraturan Pemerintah Republik Indonesia Nomor 50 Tahun 2010 Tentang Rencana Induk Pengembangan Kepariwisataan Nasional Tahun 2010-2025

Peraturan Daerah Provinsi Banten Nomor 6 Tahun 2019 Tentang Rencana Induk Pengembangan Kepariwisataan Provinsi Banten 2018-2025

Peraturan Daerah Kota Cilegon Nomor 1 Tahun 2020 Tentang Rencana Tata Ruang Wilayah 2020-2040

\section{Dokumen}

Rencana Strategis Kementerian Pariwisata Tentang Pengembangan Destinasi dan Industri Pariwisata Tahun 2015-2019.

Rencana Kerja Dinas Pariwisata dan Kebudayaan Kota Cilegon Tahun 2018

\section{Website}

Dadang Rizki Ratman, (2015) Rencana Strategis Kementeraian Pariwisata dalam https://www.kemenparekraf.go id/asset admin/assets/uploads Lmedia/pdf/media 156402153 4 RENCANA STRATEGISPENGE MBANGAN DESTINASI DAN IN DUSTRI PARIWISATA 2015 2019.pdf diunduh pada 28/02/2021

Hiramsyah S. Thaib, (2018) Strategi Pengembangan Kepariwisataan Indonesia. dalam https://www.djppr.kemenkeu.g o.id/uploads/files/Sosialisasi $\%$ 
20SBN/5.\%20Creative $\% 20$ and $\% 20$ Innovative $\% 20$ Financing $\%$ 20Forum Strategi\%20dan\%20

Kebijakan\%20Pengembangan $\%$ 20Sektor\%20Pariwisata.pdf diunduh pada 26/02/2021 